\title{
Prediction of agroforestry adoption among farming communities of Kashmir valley, India: A logistic regression approach
}

\author{
M. A. Islam*, P. A. Sofi, G. M. Bhat, A. A. Wani, A. A. Gatoo, Amerjeet Singh and A. R. \\ Malik
}

Faculty of Forestry, Sher-e-Kashmir University of Agricultural Sciences \& Technology of Kashmir, Wadura, Sopore-193201 (J\&K), INDIA.

*Corresponding author. E-mail: ajaz_jsr@yahoo.co.in

Received: February 28, 2016; Revised received: August 25, 2016; Accepted: November 16, 2016

\begin{abstract}
The study investigated the socioeconomic and psychological variables that influence the agroforestry adoption in farming communities of Kashmir. The data were collected from 142 households of 5 villages selected in Baramulla and Kupwara districts utilizing multi-stage random sampling. The results revealed that regarding agroforestry adoption majority $(52.11 \%)$ of the respondents belonged to medium category followed by low $(27.47 \%)$ and high $(20.42 \%)$ categories. The socioeconomic variables specified that the rural people are in underprivileged condition while they are in prosperous condition regarding psychological variables. The correlation analysis ( $r$ ) indicated that among explanatory variables, education, social participation, family composition, size of land holding, main occupation, housing status, farm power, farm implements, livestock possession, wealth status, gross annual income, knowledge about agrforestry, attitude towards agroforestry and level of aspiration had shown positively significant correlation with the agroforestry adoption, while, the age had a non-significant correlation. All the explanatory variables jointly accounted $90.80 \%\left(R^{2}=0.908\right)$ variation on the agroforestry adoption and among these, nine variables viz., education, size of land holding, main occupation, farm power, livestock possession, wealth status, knowledge about agrforestry, attitude towards agroforestry and level of aspiration were statistically significant $(p<0.05)$ in influencing the agroforestry adoption. The study recommends that recognition and exploitation of explanatory variables that predict agroforestry adoption, needs due consideration among policy makers, researchers and extension providers as prominent strategy for agroforestry promotion and development.
\end{abstract}

Keywords: Adoption, Agroforestry, India, Kashmir, Prediction, Psychological, Socioeconomic

\section{INTRODUCTION}

Agroforestry is the land use system which integrates trees and shrubs on farmlands and rural landscapes to enhance productivity, profitability, diversity, ecosystem sustainability and builds social institutions (Anonymous, 2014). Agroforestry offer a wide range of livelihood benefits to people e.g. higher crop yields and incomes, greater food security, natural resources conservation and better resilience to climate change that bring significant social, economic, ecological and cultural impacts for the rural societies (Mandila et al., 2015). Agroforestry technologies have been extensively researched and communicated to farming communities in developing countries like India (Roy and Tiwari, 2012; Islam et al., 2015). Like other innovation adoptions, the agroforestry adoption is a complicated process influenced not only by physical factors but also by numerous socioeconomic and psychological factors (Glover et al., 2013; Meijer et al., 2015). Since, agroforestry has different tangible and intangible costs and benefit including environmental and financial, it may not be adopted by farmers easily (Islam and Sato,
2010). Some studies (Kabwe et al., 2009; Kalabisová and Krístková, 2010; Jamala et al., 2013) suggested that successful adoption depends on favorable convergence of personal, economic, technical, institutional, extension, communication and policy factors. Despite effective extension and motivation efforts agroforestry adoption is slow and the adoption gap remains largely unexplained and underrepresented (Islam et al., 2012; Jerneck and Olsson, 2013). The decision making process to adopt agroforestry depends on external factors such as the socioeconomic characteristics and internal factors like knowledge, attitudes and aspirations simultaneously (Khandagale et al., 2012; Mwase et al., 2015). The farmer's socioeconomic variables affect adoption process overwhelmingly, then, these external factors influence internal factors like knowledge and aspirations, which in turn affect farmer's attitudes about whether or not to adopt agroforestry (Pant, 2011; Glover et al., 2013). Many studies (Sood et al., 2008; Reddy, 2011; Mandila et al., 2015) into the challenges facing agroforestry adoption have looked only at the influence of external factors while the internal psychological variables were often overlooked. Hence, both 
internal and external factors need to be considered simultaneously rather than separately in order to better understand how adoption decisions are made (Maleknia et al. 2013; Zerihun et al., 2014).

The Kashmir valley is characterized by a strong link between farming communities and agroforestry landuse system and by particular attention to agroforestry multi-functionality (Banyal et al., 2011). Agroforestry have become a rural way of life in Kashmir valley since time immemorial (Islam et al., 2012). The common agroforestry systems being practiced traditionally are agri-silvi-horticulture and homestead forestry. The woody and fruit tree species most commonly adopted in agroforestry are Salix alba, Populus deltoides, Robinia pseudoacacia, Populus nigra, Morus alba, Juglans regia, Ulmus wallichiana, Ailanthus excelsa, Malus domestica, Pyrus communis, Prunus persica, Prunus armeniaca etc. Despite all its merits, agroforestry adoption rate falls far behind the projected (Banyal et al., 2011). The socioeconomic inequalities and disparity in psychological attributes in farming communities play significant differential role in agroforestry adoption (Kabwe et al., 2009; Jamala et al., 2013). To promote agroforestry adoption, a deeper understanding of people's socioeconomic and psychological factors influencing agroforestry adoption is essential for better planning and implementation of agroforestry extension and motivation programmes. Undertaking these facts, this study has been designed to determine the socioeconomic and psychological attributes that influence the agroforestry adoption in farming communities of Kashmir, as a basis to develop prediction model which may facilitate policymakers to devise measures to support and encourage sustainable agroforestry land use.

\section{MATERIALS AND METHODS}

Study site: The study was conducted in Baramulla and Kupwara districts in north-western region of Kashmir valley located between geographical co-ordinates of $24.03^{\circ} 06^{\prime} \mathrm{N}$ Longitude and $74.26^{\circ} 45^{\prime}$ E Latitude at an altitude of 1593 meter above MSL. The region is characterized by temperate monsoon type of climate. The mean minimum (January) and maximum (June) temperatures are $29.8^{\circ} \mathrm{C}$ and $-1.92^{\circ} \mathrm{C}$, respectively, with average annual precipitation of $1163.2 \mathrm{~mm}$ during 2014-15. Land use in the region is mostly dominated by cultivated land, permanent pastures, nonagricultural uses, barren and uncultivable land, other fallows, current fallows, forest land and tree cover and groves. The area studied in the districts was the stretch along Langate Forest Division of Jammu and Kashmir (Anonymous, 2011).

Sampling technique: Multi-stage random sampling technique (Ray and Mondol, 2004) was employed to select the villages and respondents. The first stage was the random selection of two blocks namely, Langate of
Handwara tehsil in Kupwara district and Dangiwacha of Rohama tehsil in Baramulla district. The second stage involved simple random sampling of three villages viz., Yunsu, Chogal and Wahipora from Langate block and two villages viz., Ganipora and Behrampura from Dangiwacha block. A total of 142 households were drawn from the sample villages having 10 percent sampling intensity for the field study. The respondents interviewed were either household heads or eldest members.

Collection of data: Data were collected using a well structured pre-tested interview schedule and nonparticipant observation (Kumar, 2012). Interview schedule was prepared on the basis of earlier works, reconnaissance survey, discussion with the local people and consultation with the experts. The interview schedule included household level informations on socioeconomic and psychological variables and agroforestry adoption. Under non-participant observation, the data were recorded by watching and noting the phenomena.

Empirical measurements of variables: The socioeconomic variables involved in the logistic regression model for agroforestry adoption were measured (Table 1) using the scale of Venkataramaiah (1990). The knowledge scale of Kumar (2001) was used to determine the extent of knowledge about agroforestry $\left(\mathrm{X}_{13}\right)$. Ten important agroforestry practices were incorporated in the schedule provided with a four point response categories as; no knowledge at all (0), to a little extent (1), to a moderate extent (2) and to a large extent (3). The summation of scores over all the practices indicated the knowledge level. The attitude towards agroforestry $\left(\mathrm{X}_{14}\right)$ was measured using the scale of Sreenath and Veerabhadraiah (1993). The scale was consisted of ten especially structured statements, the agreements or disagreements of which were recorded on five point continuum viz., strongly agree, agree, undecided, disagree and strongly disagree with their respective scores of 5, 4, 3, 2 and 1 . The total score indicated the individual's attitude toward agroforestry. The level of aspiration $\left(\mathrm{X}_{15}\right)$ was assessed using scale of Supe and Singh (1969) based on five items namely, children's education, increase in income, agricultural implements, material possession and increase in livestock. These items were assigned appropriate scores and the summation indicated individual's level of aspiration.

The agroforestry adoption (Y) was measured using scale of Nagesha and Gangadharappa (2006). Ten important agroforestry practices were listed in the schedule and the adoption responses were recorded as; non adoption, partial adoption and full adoption with their respective scores of 0,1 and 2 , respectively. The ranking of agroforestry practices was done from 1 to 10 on the basis of their weighted mean score (WMS) as per Islam et al. (2015). The respondents were classified into three categories of low, medium and high level of agroforestry adoption using mean and standard deviation following Nagesha and Gangadharappa (2006). 
Data analysis: The data were analyzed on MS Excel and Statistical Package for Social Sciences (SPSS) software with the level of significance set at $\mathrm{p}<0.05$. The statistical tools viz., frequency (f), percentage (\%), average $(\mathrm{x})$, standard deviation, range, co-efficient of correlation, multiple regression and $\mathrm{F}$ test were applied for data analysis as per Snedecor and Cochran (1967). A linear logistic regression model, which considered agroforestry adoption as dependent variable versus explanatory variables as predictor variables was derived as stated by Neupane et al. (2002).

\section{RESULTS AND DISCUSSION}

Agroforestry adoption: The relative adoption of agroforestry practices (Table 2) indicated that the practice of grading and sale of agroforest products was fully adopted by majority $(84.51 \%)$ of the respondents and ranked $1^{\text {st }}$ (WMS, 1.85$)$. The next utmost $(83.10 \%)$ fully adopted practice was time and stage of harvesting of agroforest products which was ranked $2^{\text {nd }}$ (WMS, $1.83)$. Similarly, a substantial majority $(75.35 \%)$ had adopted the practice of extraction and processing of agroforest products fully and assigned the rank $3^{\text {rd }}$ (WMS, 1.74). Regarding the practice of application of fertilizers and manures for trees most (53.52\%) of the respondents have shown full adoption and rated it $4^{\text {th }}$ (WMS, 1.44). The practice of soil working methods for tree planting was adopted fully among $52.11 \%$ of the respondents ranking it at $5^{\text {th }}$ (WMS, 1.41). As regards, the other practices namely, tending operations (e.g. weeding, cleaning, thinning, crown manipulation etc.), protection measures (e.g. insect/ pest manage- ment, disease control etc.), preparation of tree planting material, spacing \& plantation geometry and multipurpose trees and shrubs, the adoption level were partial with WMS ranging between 1.27 to 0.96 and thus, the ranks assigned were $6^{\text {th }}$ to $10^{\text {th }}$ respectively. The practices ranked $1^{\text {st }}$ to $3^{\text {rd }}$ were significantly different $(p<$ 0.05 ) with the practices ranked $4^{\text {th }}$ to $10^{\text {th }}$. The classification of respondents based on mean (13.20) and standard deviation (3.23) of adoption scores (Table 3) revealed that majority $(52.11 \%)$ of them belonged to medium category followed by low (27.47\%) and high $(20.42 \%)$ categories. The adoption score ranged from 7.00 to 20.00 .

The harvesting, processing, grading and marketing of forest resources needs special care (Nagesha and Gangadharappa, 2006) and active involvement of the people to acquire maximum economic return (Quli and Singh, 2010), that's why respondents have shown more interest and full adoption towards these practices. On the contrary, the practices like application of fertilizers and manures for trees and soil working methods for tree planting are carried out frequently whenever considered necessary. As application of these operations is common for agricultural crops and practiced by almost all the farmers; no special arrangement is required for tree planting (Islam et al., 2012). With respect to the other forestry practices viz., tending operations (e.g. weeding, cleaning, thinning, crown manipulation etc.), protection measures (e.g. insect/ pest management, disease control etc.), preparation of tree planting material, spacing \& plantation geometry and multipurpose trees and shrubs, most of the farmers

Table 1. Description of the socioeconomic variables.

\begin{tabular}{|c|c|}
\hline Variable (Code) & Description \\
\hline Age $\left(\mathrm{X}_{1}\right)$ & Chronological age in year \\
\hline Education $\left(\mathrm{X}_{2}\right)$ & $\begin{array}{l}0=\text { illiterate }, 1=\text { below primary, } 2=\text { primary, } 3=\text { middle, } 4=\text { high school, } 5=\text { intermediate }, \\
6=\text { graduate } \& \text { above }\end{array}$ \\
\hline Social participation $\left(\mathrm{X}_{3}\right)$ & $\begin{array}{l}0=\text { no participation, } 1=\text { membership of } 1 \text { organization, } 2=\text { membership of }>1 \text { organization, } \\
3=\text { office bearer, } 4=\text { public leader }\end{array}$ \\
\hline Family composition $\left(\mathrm{X}_{4}\right)$ & Family type: $1=$ Nuclear, $2=$ Joint; Family size: $1=$ upto 5 members, $2=>5$ members \\
\hline Size of land holding $\left(\mathrm{X}_{5}\right)$ & $\begin{array}{l}0=\text { landless }, 1=\text { marginal (upto } 1.0 \mathrm{ha}), 2=\text { small }(1.1 \text { to } 2.0 \mathrm{ha}), 3=\text { medium }(2.1 \text { to } 4.0 \mathrm{ha}), \\
4=\text { large }(>4.0 \mathrm{ha})\end{array}$ \\
\hline Main occupation $\left(\mathrm{X}_{6}\right)$ & $\begin{array}{l}1=\text { wage labour, } 2=\text { caste occupation, } 3=\text { cultivation, } 4=\text { business, } 5=\text { service, } 6=\text { any } \\
\text { other }\end{array}$ \\
\hline Housing status $\left(\mathrm{X}_{7}\right)$ & $\begin{array}{l}\text { Type: } 0=\text { no house, } 1=\text { hut, } 2=\text { temporary structure, } 3=\text { mixed, } 4=\text { permanent structure; } \\
\text { Number of rooms: } 1=01,2=02,3=>02\end{array}$ \\
\hline Farm power $\left(\mathrm{X}_{8}\right)$ & $0=$ no bullock, $1=1-2$ bullocks, $2=3-4$ bullocks, $3=5-6$ bullocks \\
\hline Farm implements $\left(\mathrm{X}_{9}\right)$ & $\begin{array}{l}0=\text { no farm implements, } 1=\text { wooden plough, } 1=\text { sickle, } 1=\text { spade, } 1=\text { axe, } 1=\text { harrow, } 2= \\
\text { power tiller, } 2=\text { bullock cart, } 2=\text { pump set, } 2=\text { duster, } 2=\text { sprayer, } 2=\text { electric motor, } 4= \\
\text { tractor }\end{array}$ \\
\hline Livestock possession $\left(\mathrm{X}_{10}\right)$ & $0=$ no livestock, $1=$ upto 5 livestock, $2=6$ to 10 livestock, $3=$ more than 10 livestock \\
\hline Wealth status $\left(\mathrm{X}_{11}\right)$ & $\begin{array}{l}1=\text { smokeless crude oven, } 1=\text { stove, } 1=\text { sewing machine, } 1=\text { watch, } 1=\text { cycle, } 1=\text { radio, } 1= \\
\text { wooden furniture, } 1=\text { pressure cooker, } 2=\text { improved storage bin, } 2=\text { tape recorder, } 3=\text { scoot- } \\
\text { er } / \text { motor cycle, } 1=\text { any other }\end{array}$ \\
\hline Gross annual income $\left(\mathrm{X}_{12}\right)$ & Rs./ annum \\
\hline
\end{tabular}


Table 2. Adoption of agroforestry practices among farming households $(\mathrm{N}=142)$.

\begin{tabular}{|c|c|c|c|c|c|}
\hline \multirow[t]{2}{*}{ Agroforestry practices } & \multicolumn{3}{|c|}{ Adoption response category } & \multirow[t]{2}{*}{ WMS } & \multirow{2}{*}{$\begin{array}{l}\text { Mean } \\
\text { rank }\end{array}$} \\
\hline & Full & Partial & No & & \\
\hline Multipurpose trees and shrubs & $44(30.99)$ & $48(33.80)$ & $50(35.21)$ & $0.96^{\mathrm{b}}$ & 10 \\
\hline Preparation of tree planting material & $48(33.80)$ & $45(31.69)$ & $49(34.51)$ & $0.99^{\mathrm{b}}$ & 8 \\
\hline Soil working methods for tree planting & $74(52.11)$ & $52(36.62)$ & $16(11.27)$ & $1.41^{\mathrm{b}}$ & 5 \\
\hline Spacing \& plantation geometry & $45(31.69)$ & $50(35.21)$ & $47(33.10)$ & $0.98^{\mathrm{b}}$ & 9 \\
\hline $\begin{array}{l}\text { Tending operations (e.g. weeding, cleaning, thinning, } \\
\text { crown manipulation etc.) }\end{array}$ & $63(44.37)$ & $55(38.73)$ & $24(16.90)$ & $1.27^{\mathrm{b}}$ & 6 \\
\hline $\begin{array}{l}\text { Protection measures (e.g. insect/ pest management, disease } \\
\text { control etc.) }\end{array}$ & $34(23.94)$ & $77(54.23)$ & $31(21.83)$ & $1.02^{\mathrm{b}}$ & 7 \\
\hline Application of fertilizers and manures for trees & $76(53.52)$ & $53(37.32)$ & $13(9.16)$ & $1.44^{\mathrm{b}}$ & 4 \\
\hline Time and stage of harvesting of agroforest products & $118(83.10)$ & $24(16.90)$ & $0.00(0.00)$ & $1.83^{\mathrm{a}}$ & 2 \\
\hline Extraction and processing of agroforest products & $107(75.35)$ & $33(23.24)$ & $02(1.41)$ & $1.74^{\mathrm{a}}$ & 3 \\
\hline Grading and sale of agroforest products & $120(84.51)$ & $22(15.49)$ & $0.00(0.00)$ & $1.85^{\mathrm{a}}$ & 1 \\
\hline
\end{tabular}

WMS $=$ Weighted mean score; Figures in the parentheses indicate percentages; WMS followed by different superscript letters within the column are significantly different $(\mathrm{p}<0.05)$.

Table 3. Univariate analysis of agroforestry adoption among farming households $(\mathrm{N}=142)$.

\begin{tabular}{lllll}
\hline Category (Scores) & Respondents (\%) & Minimum & Maximum & 95\% Confidence Interval \\
\hline Low $(<9.97)$ & $39(27.47)$ & 7.00 & 20.00 & $12.66-13.74$ \\
Medium $(10.18$ to 16.43$)$ & $74(52.11)$ & & & \\
High $(>16.43)$ & $29(20.42)$ & & & \\
\hline
\end{tabular}

Table 4. Descriptive statistics for socioeconomic and psychological variables of farming households $(\mathrm{N}=142)$.

\begin{tabular}{|c|c|c|c|c|c|c|}
\hline \multirow[t]{2}{*}{ Variable (Code) } & \multirow[t]{2}{*}{ Mean } & \multirow[t]{2}{*}{ Std. Dev. } & \multicolumn{2}{|c|}{ 95\% Confidence Interval for Mean } & \multirow[t]{2}{*}{ Minimum } & \multirow[t]{2}{*}{ Maximum } \\
\hline & & & Lower Bound & Upper Bound & & \\
\hline Age $\left(\mathrm{X}_{1}\right)$ & 41.75 & 9.53 & 40.17 & 43.33 & 25 & 56 \\
\hline Education $\left(\mathrm{X}_{2}\right)$ & 2.89 & 0.93 & 2.73 & 3.04 & 2 & 6 \\
\hline Social participation $\left(\mathrm{X}_{3}\right)$ & 1.14 & 1.20 & 0.94 & 1.34 & 0 & 4 \\
\hline Family composition $\left(\mathrm{X}_{4}\right)$ & 2.90 & 0.88 & 2.76 & 3.05 & 2 & 4 \\
\hline Size of land holding $\left(\mathrm{X}_{5}\right)$ & 1.15 & 0.53 & 1.06 & 1.24 & 1 & 4 \\
\hline Main occupation $\left(\mathrm{X}_{6}\right)$ & 2.80 & 1.20 & 2.61 & 3.00 & 1 & 6 \\
\hline Housing status $\left(\mathrm{X}_{7}\right)$ & 3.57 & 1.01 & 3.40 & 3.74 & 2 & 6 \\
\hline Farm power $\left(\mathrm{X}_{8}\right)$ & 1.04 & 0.64 & 0.94 & 1.15 & 0 & 3 \\
\hline Farm implements $\left(\mathrm{X}_{9}\right)$ & 9.64 & 3.78 & 9.01 & 10.27 & 4 & 17 \\
\hline Livestock possession $\left(\mathrm{X}_{10}\right)$ & 1.91 & 0.56 & 1.82 & 2.00 & 0 & 3 \\
\hline Wealth status $\left(\mathrm{X}_{11}\right)$ & 8.09 & 3.36 & 7.53 & 8.65 & 2 & 15 \\
\hline Gross annual income $\left(\mathrm{X}_{12}\right)$ & 50887.32 & 21134.19 & 47381.15 & 54393.49 & 18000 & 95000 \\
\hline $\begin{array}{l}\text { Knowledge about agrforestry } \\
\left(\mathrm{X}_{13}\right)\end{array}$ & 24.01 & 3.28 & 23.46 & 24.55 & 15 & 29 \\
\hline Attitude towards agroforestry & 32.38 & 5.17 & 31.52 & 33.24 & 21 & 40 \\
\hline Level of aspiration $\left(\mathrm{X}_{15}\right)$ & 21.60 & 4.16 & 20.91 & 22.29 & 14 & 32 \\
\hline
\end{tabular}

were either having little knowledge (Roy and Tiwari, 2012), or considered unimportant (Jerneck and Olsson, 2013) which resulted in partial adoption. In a nutshell, the overall extent of agroforestry adoption among majority of the farmers is moderate. The prevalence of respondents falling under medium category of adoption further substantiate that the magnitude of agroforestry adoption in farming communities is unsatisfactory which could be due to inadequate knowledge regarding complex agroforestry practices (Nagesha and Gangadharappa, 2006), unscientific tree farming (Quli and Singh, 2010), widespread use of primitive indigenous techniques (Quli and Singh, 2010), ignorance towards modern technologies (Roy and Tiwari, 2012), poor extension contact and participation (Islam et al., 2012), problems in availability of quality input materials and tools and stumpy financial status (Jerneck and Olsson, 2013).

Farmer's profile: The averages of socioeconomic variables for the farming households (Table 4) signified the predominance of middle aged people $(41.75$ years) having low literacy (2.89), membership of only one organization (1.14), nuclear and large sized families (2.90), marginal sized land holding (1.15), engaged mainly in agriculture (2.80), owning one mixed or permanent house (3.57), one pair of bullocks (1.04), 
Table 5. Correlation and multiple regression analysis of socioeconomic and psychological variables with agroforestry adoption $(\mathrm{N}=142)$.

\begin{tabular}{|c|c|c|c|c|}
\hline Variable (Code) & $\begin{array}{l}\text { Co-efficient of } \\
\text { correlation (r) }\end{array}$ & $\begin{array}{l}\text { Regression } \\
\text { co-efficient (b) }\end{array}$ & $\begin{array}{l}\text { Standard error } \\
\text { of ' } b \text { ' }\end{array}$ & 't' value \\
\hline Age $\left(X_{1}\right)$ & 0.028 & 0.025 & 0.010 & 1.616 \\
\hline Education $\left(\mathrm{X}_{2}\right)$ & $0.705^{*}$ & 0.325 & 0.149 & $2.177^{*}$ \\
\hline Social participation $\left(\mathrm{X}_{3}\right)$ & $0.743^{*}$ & -0.089 & 0.143 & -0.620 \\
\hline Family composition $\left(\mathrm{X}_{4}\right)$ & $0.654^{*}$ & 0.204 & 0.152 & 1.342 \\
\hline Size of land holding $\left(\mathrm{X}_{5}\right)$ & $0.638^{*}$ & 0.793 & 0.242 & $3.276^{*}$ \\
\hline Main occupation $\left(\mathrm{X}_{6}\right)$ & $0.648^{*}$ & 0.423 & 0.107 & $3.960^{*}$ \\
\hline Housing status $\left(\mathrm{X}_{7}\right)$ & $0.600^{*}$ & 0.074 & 0.123 & 0.605 \\
\hline Farm power $\left(\mathrm{X}_{8}\right)$ & $0.575^{*}$ & 0.416 & 0.171 & $2.429^{*}$ \\
\hline Farm implements $\left(\mathrm{X}_{9}\right)$ & $0.560^{*}$ & 0.006 & 0.033 & 0.193 \\
\hline Livestock possession $\left(\mathrm{X}_{10}\right)$ & $0.612^{*}$ & 0.734 & 0.213 & $3.456^{*}$ \\
\hline Wealth status $\left(\mathrm{X}_{11}\right)$ & $0.559^{*}$ & 0.140 & 0.031 & $4.472^{*}$ \\
\hline Gross annual income $\left(\mathrm{X}_{12}\right)$ & $0.778^{*}$ & 1.164 & 0.000 & 1.514 \\
\hline Knowledge about agrforestry $\left(\mathrm{X}_{13}\right)$ & $0.771^{*}$ & 0.129 & 0.049 & $2.661^{*}$ \\
\hline Attitude towards agroforestry $\left(\mathrm{X}_{14}\right)$ & $0.741^{*}$ & 0.093 & 0.028 & $3.276^{*}$ \\
\hline Level of aspiration $\left(\mathrm{X}_{15}\right)$ & $0.752^{*}$ & 0.154 & 0.034 & $4.509^{*}$ \\
\hline
\end{tabular}

$\mathrm{a}=-4.71 ; \mathrm{F}=83.394 * ; \mathrm{R}^{2}=0.908 ;$ Multiple $\mathrm{R}=0.953 ;$ Adjusted $\mathrm{R}^{2}=0.898 ; *=$ Significant at $5 \%$ level of probability

low farm implements possession (9.64), 6 to 10 livestock (1.91), low wealth status (8.09) and earning average gross annual income of Rs. 50887.32. Conversely, the psychological variables averaged showed prevalence of respondents having moderate extent of knowledge about agrforestry (24.01), attitude towards agrforestry (32.38) and aspiration level (21.60). The farmers are in underprivileged condition as exemplified by their socioeconomic profile while they are in prosperous position concerning psychological variables. It implies that the psychological variables should be exploited efficiently for people's socioeconomic improvement through exemplary agroforestry adoption. Several socioeconomic attributes such as low education (Bijalwan et al., 2011), small sized land holding (Islam et al., 2012), inadequate farm power and implements (Roy et al., 2012), etc. constituted the major constraints to agroforestry adoption as a comprehensive form of socio-technological change.

Correlation analysis: Correlation analysis (Table 5.) indicated that among explanatory variables, education (0.705), social participation (0.743), family composition (0.654), size of land holding (0.638), main occupation (0.648), housing status (0.600), farm power (0.575), farm implements $(0.560)$, livestock possession (0.612), wealth status (0.559), gross annual income (0.778), knowledge about agrforestry (0.771), attitude towards agroforestry (0.741) and level of aspiration $(0.752)$ had significant positive ' $r$ ' values with the agroforestry adoption, while, the age (0.028) exhibited non-significant ' $r$ ' value. The non-significance of the age of farming household heads suggests that the agroforestry adoption is independent of age. The positive significant correlation of education with agroforestry adoption is expressed by the facts that the education resulted in bringing desirable changes in human behav- ior and helped the people to move in right direction (Arunachalam and Arunachalam, 2012), the agroforestry knowledge is built up through education which made them aware of new agroforestry innovations (Sood et al., 2008), and the change in attitude is partly a function of education (Banyal et al., 2011). Likewise, the positive significant correlation between social participation and agroforestry adoption can be explained by the facts that this variable paves the way for the farming people to share their views and experiences with other members of the organization (Bijalwan et $a l ., 2011$ ), to clarify their doubts and get opinion from diverse people and enrich their knowledge (Sood et al., 2008). Farmers with nuclear families have taken up independent decisions conveniently to adopt agroforestry (Zerihun et al., 2014) and further, larger sized families were having more labour force and opportunities resulting in higher agroforestry adoption (Khandagale et al., 2012). The positive significant correlation of family composition with agroforestry adoption confirms this articulation. The people who have big size of land holding were having good economic condition and physical assets (Jamala et al., 2013) and more scope and opportunities for agroforestry adoption (Kabwe et al., 2009), thus, the size of land holding was found to be positively significant determinant in agroforestry adoption. The main occupation of the rural people exhibited direct bearing on the earnings and effected the possession of livelihood assets (Kalabisová and Krístková, 2010) that's why people occupied in farming as their main profession have higher agroforestry adoption. The other economic variables viz., housing status, farm power, farm implements, livestock possession and wealth status are the key indicators, core contributors and the representatives of physical capital owned by the rural people 
(Maleknia et al., 2013) which play an important role in their socio-economy (Pant, 2011) and help them to develop other types of capitals to be owned and traded (Reddy, 2011). These variables thus, had showed positive and significant correlation with the agroforestry adoption. The positive significant correlation of gross annual income with agroforestry adoption could be attributed to the fact that this variable is the major indicator of financial capital possessed by the households (Mandila et al., 2015), which occupies central position governing the livelihood security and sustainability (Arunachalam and Arunachalam, 2012).

The ample knowledge of agroforestry assist the people to carry out the nursery operations, tree plantation, protection and management of plantation, harvesting, conversion and processing of forest products, household consumption of forest products and grading and sale of forest produces in a better way, which enhance the yield, fetch higher financial returns (Banyal et al., 2011) and give a window of opportunity to achieve livelihood security. Our result about knowledge of agroforestry confirms this explanation. The positive significant correlation of attitude with agroforestry adoption is because of the fact that the positive and favourable attitude develops self-confidence and motivation in adoption of new technologies and innovations in agroforestry which creates new livelihood options for socioeconomic development (Bijalwan et al., 2011). As the level of aspiration concerns with the future level of possible achievement, socioeconomic improvement and household security (Glover et al., 2013), it implies that higher the level of aspiration, the higher would be the agroforestry adoption.

Multiple regression analysis: The values of regression coefficients for the explanatory variables (Table 5.) were, age (0.025), education $(0.325)$, social participation (-0.089), family composition (0.204), size of land holding (0.793), main occupation (0.423), housing status (0.074), farm power (0.416), farm implements (0.006), livestock possession (0.734), wealth status (0.140), gross annual income (1.164), knowledge about agrforestry (0.129), attitude towards agroforestry (0.093) and level of aspiration (0.154). The calculated ' $\mathrm{t}$ ' values were when compared with table ' $\mathrm{t}$ ' values, it was found that the variables viz., education (2.177), size of land holding (3.276), main occupation (3.960), farm power (2.429), livestock possession (3.456), wealth status (4.472), knowledge about agrforestry (2.661), attitude towards agroforestry (3.276) and level of aspiration (4.509) were statistically significant in influencing the agroforestry adoption. The coefficient of determination $\left(\mathrm{R}^{2}\right)$ of 0.908 implies that all the explanatory variables had jointly explained $90.80 \%$ of variation on the agroforestry adoption. The F value (83.394) indicated that the $\mathrm{R}^{2}$ is statistically significant $(\mathrm{p}<0.05)$.

The analysis indicated that among fifteen independent variables, nine variables viz., education, size of land holding, main occupation, farm power, livestock possession, wealth status, knowledge about agrforestry, attitude towards agroforestry and level of aspiration had significant contribution to the agroforestry adoption and thus, were the potential predictors in explaining the variation in the agroforestry adoption. The education plays a crucial in awareness development, enhancement in technical know-how, decision making, motivation and adoption of agroforestry (Sood et al., 2008; Kabwe et al., 2009; Kalabisová and Krístková, 2010). The variables like, size of land holding, main occupation, farm power, livestock possession and wealth status are the prominent household physical and financial resources which have direct linkages with agroforestry adoption (Islam and Quli, 2016). As regards, knowledge about agrforestry and attitude towards agroforestry, the success or failure of agroforestry adoption directly rests on scale of these variables. While, sufficient knowledge is essential for agroforerstry establishment, sustainable management and extraction of ecosystem goods and services (Glover et al., 2013; Behera and Pattanayak, 2016), the unfavourable or negative attitude towards agroforestry can oblige people for discontinuance or non-adoption (Jamala et al., 2013; Maleknia et al., 2013). Likewise, the level of aspiration has direct influences on farmer's future expectations, possible achievement, positivism, decision making, self-confidence, motivation, socioeconomic soundness, household security etc., thus, facilitate agroforestry adoption (Zerihun et al., 2014; Mandila et al., 2015; Mwase et al., 2015). The fitted multiple regression equation for agroforestry adoption should be given as:

$$
\mathrm{Y}=-4.716+0.025 \mathrm{X}_{1}+0.325 \mathrm{X}_{2}-0.089 \mathrm{X}_{3}+
$$
$0.204 X_{4}+0.793 X_{5}+0.423 X_{6}+0.074 X_{7}+0.416 X_{8}+$ $0.006 \mathrm{X}_{9}+0.734 \mathrm{X}_{10}+0.140 \mathrm{X}_{11}+1.164 \mathrm{X}_{12}+$ $0.129 \mathrm{X}_{13}+0.093 \mathrm{X}_{14}+0.154 \mathrm{X}_{15}$

Where $\mathrm{Y}=$ agroforestry adoption (score)

$\mathrm{X}_{1}-\mathrm{X}_{15}=$ explanatory variables

The $F$ value (83.394) confirmed that the analysis was significant $(p<0.05)$ and the explanatory variables explained significantly the variation in the agroforestry adoption, thus, the model is fit to make the quantitative predictions of extent of agroforestry adoption. To sum up, the agroforestry adoption is a function earnestly determined by the existing socioeconomic and psychological dynamics (Jerneck and Olsson, 2013).

\section{Conclusion}

Farmer's decision to adopt agroforestry practices primarily depends on favourable convergence of socioeconomic and psychological variables, consideration of which is imperative during agroforestry planning and implementation to make the intervention successful. The agroforestry technology is difficult to establish in rural Kashmir because the understanding of how agroforestry operates, or fails to operate, in multifunctional 
landscapes is incomplete and the people are notoriously difficult to reach precisely. In response, the study has shown how the agroforestry adoption is influenced by the socioeconomic and psychological factors. In the research, the overall adoption of agroforestry practices in rural communities is moderate. The rural people are underprivileged with regard to their socioeconomic conditions while they are prosperous pertaining to their psychological variables. Hence, there is a wide scope for improvement in socioeconomic status of the rural people through promotion and strengthening the adoption of agroforestry technologies. It is confirmed that the decision on agroforestry adoption by farmers is a function of myriad of socioeconomic and psychological variables. If farmers cannot satisfy these socioeconomic and psychological variables it will block the path to agroforestry adoption as a complex activity. The findings and perspective provide guidance toward appropriating the socioeconomic and psychological scenarios for policy makers, researchers and extension workers in designing the necessary agroforestry support measures to accelerate and reinforce the agroforestry adoption and sustainable livelihood. Further, the regression model can be used to predict the extent of agroforestry adoption considering the structured set of explanatory variables signified in the study.

\section{ACKNOWLEDGEMENTS}

Our deep thanks to everyone who brought their contributions to this paper and for kindly sharing ideas, comments, and suggestions. Special thanks to Forestry scholars of the Faculty of Forestry, SKUAST-K, Wadura, Sopore, Kashmir for providing support during our field-work.

\section{REFERENCES}

Anonymous (2011). Directorate of Economics and Statistics, District Statistics and Evaluation Office, Baramulla, Jammu and Kashmir.

Anonymous (2014). National Agroforestry Policy, Dept. of Agriculture \& Cooperation, Ministry of Agriculture, Govt. of India, pp. 13.

Arunachalam, K. and Arunachalam, A. (2012). Role of agroforestry in human livelihoods and biodiversity management. Indian Journal of Agroforestry, 14(1): 97-100

Banyal, R., Masoodi, N.A., Masoodi, T.H., Sharma, L.K. and Gangoo, S.A. (2011). Knowledge and attitude of farmers towards agroforestry practices in north Kashmir- a case study. The Indian For., 137(12): 1377-1381

Behera, S. and Pattanayak, S. (2016). Agroforestry: A suitable system for soil health enhancement. Advances in Life Sciences, 5(10): 3922-3925

Bijalwan, A., Sharma, C.M. and Kediyal, V.K. (2011). Socioeconomic status and livelihood support through traditional agroforestry systems in hill and mountain agroecosystem of Garhwal Himalaya, India. The Indian For., 138(12): 1423-1430

Glover, E.K., Ahmed, H.B. and Glover, M.K. (2013). Analysis of socio-economic conditions influencing adoption of agroforestry practices. International Journal of Agriculture and Forestry, 3(4): 178-184

Islam, M.A., Masoodi, T.H., Gangoo, S.A., Sofi, P.A., Bhat, G.M., Wani, A.A., Gatoo, A.A., Singh, A. and Malik, A.R. (2015). Perceptions, attitudes and preferences in agroforestry among rural societies of Kashmir, India. Journal of Applied and Natural Science, 7(2): 976-983

Islam, K.K. and Sato, N. (2010). Constraints of participatory agroforestry program to poverty alleviation: The case of the sal forests, Bangladesh. American-Eurasian $J$. Agric. \& Environ. Sci., 9(4): 427-435

Islam, M.A. and Quli, S.M.S. (2016). Motivation strategy for agroforestry intensification among small holders. $A d$ vances in Life Sciences, 5(10): 3878-3883

Islam, M.A., Banyal, R., Rai, R. and Singh, P.K. (2012). Determinant factors of agroforestry adoption in North Kashmir. Indian j Soc Res., 53(2): 123-129

Jamala, G.Y., Shehu, H.E., Yidau, J.J. and Joel, L. (2013). Factors influencing adoption of agroforestry among smallholder farmers in Toungo, Southeastern, Adamawa State, Nigeria. IOSR Journal of Environmental Science, Toxicology and Food Technology, 6(6): 66-72

Jerneck, A. and Olsson, L. (2013). More than trees! Understanding the agroforestry adoption gap in subsistence agriculture: Insights from narrative walks in Kenya. Journal of Rural Studies, 32: 114-125

Kabwe, G., Bigsby, H. and Cullen, R. (2009). Factors influencing adoption of agroforestry among smallholder farmers in Zambia. Paper presented at the 2009 NZARES Conference, Tahuna Conference Centre Nelson, New Zealand. August 27-28, 2009

Kalabisová, J. and Krístková, Z. (2010). Valuing socioeconomic factors of farmers' households and economic effects of agroforestry system. Economics and Informatics, 2(4): 11-22

Khandagale, A.S., Taide, Y.B., Deshmukh, H.K. and Thigale, M.B. (2012). Constraints faced by growers in adoption of recommended practices of teak. Indian J. of Agroforestry, 14(1): 45-48

Kumar, G.T.P. (2001). A study on agroforestry among rehabilitated tribals in Mysore district. Ph.D. Thesis (Unpublished), University of Agricultural Sciences, Bangalore

Kumar, R. (2012). Research Methodology - A step by step guide for beginners. Dorling Kindersley (India) Pvt. Ltd., New Delhi, India.

Maleknia, R., Beyranvand, Z., Sosaniand, J. and Adeli, K. (2013). Factors affecting agroforestry acceptance level by framers. Agriculture Science Developments, 2(10): 102-105

Mandila, B., Hitimana, J. Kiplagat, A., Mengich, E. and Wekesa, T. (2015). Prevalence and adoption of agroforestry technologies and practices in semi-arid regions of West-Pokot County, Kenya. Research Journal of Agriculture and Forestry Sciences, 3(6): 6-15

Meijer, S.S., Catacutan, D., Ajayi, O.C., Sileshi, G.W. and Nieuwenhuis, M. (2015). The role of knowledge, attitudes and perceptions in the uptake of agricultural and agroforestry innovations among smallholder farmers in sub-Saharan Africa. International Journal of Agricultural Sustainability, 9(2): 57-66

Mwase, W., Sefasi, A., Njoloma, J., Nyoka, B.I., Manduwa, D. and Nyaika, J. (2015). Factors affecting adoption of 
agroforestry and evergreen agriculture in Southern Africa. Environment and Natural Resources Research, 5(2): $148-157$

Nagesha, G. and Gangadharappa, N.B. (2006). Adoption of agroforestry systems in north eastern districts of Karnataka. My Forest, 42(4): 337-347

Neupane, R.P., Sharma, K.R. and Thapa, G.B. (2002). Adoption of agroforestry in the hills of Nepal: A logistic regression analysis. Agricultural Systems, 72: 177-196

Pant, N. (2011). Motivational factors in activities of agroforestry - a case study. The Indian For., 137(3): 363-569

Quli, S.M.S. and Singh, P.K. (2010). Choice of species for traditional agroforestry by tribes in Jharkhand. Jharkhand J. Develop. Manag. Stud., 8(1): 3727-3735

Ray, G.L. and Mondol, S. (2004). Research Methods in Social Sciences and Extension Education, Kalyani Publishers, New Delhi, 66-76

Reddy, E.V. (2011). Constraints in marketing of agroforestry produce in India. The Indian For., 137(6): 669-677

Roy, M.M. and Tiwari, J.C. (2012). Agroforestry for climate resilient agriculture and livelihood in arid region of In- dia. Indian J. of Agroforestry, 14(1): 49-59

Snedecor, G.W. and Cochran, W.G. (1967). Statistical Methods. Iowa State University Press, Ames, Iowa-50010

Sood, K.K., Najiar, C., Singh, K.A., Handique, P., Singh, B. and Rethy, P. (2008). Association between socioeconomic parameters and agroforestry uptake: evidences from eastern Himalaya, Indian J. For., 31(4): 559-564

Sreenath, D. and Veerabhadraiah, V. (1993). A study on the attitude of farmers towards social forestry programme. My Forest, 29(2): 117-120

Supe, S.V. and Singh, S.N. (1969). Dynamics of rational behaviours. New publishers and distributors, New Delhi.

Venkataramaiah, P. (1990). Development of socio-economic status scale, Ph.D. Thesis, Department of Agricultural Extension, UAS, Bangalore.

Zerihun, M.F., Muchie, M. and Worku, Z. (2014). Determinants of agroforestry technology adoption in Eastern Cape Province, South Africa. Development Studies Research: An Open Access Journal, 1(1): 382-394 